\title{
FACTOR PROMOTING WOUND HEALING: RADICAL SCAVENGING AND ANTI-INFLAMMATORY ACTIVITY AND GROWTH FACTOR PROMOTION OF HELIOTROPIUM INDICUM
}

\author{
NAKUNTWALAI WISIDSRI*, SURADWADEE THUNGMUNGMEE, WARACHATE KHOBJAI
}

Department of Thai Traditional Medicine, Thai Traditional Medicine College, Rajamangala University of Technology Thanyaburi, Pathum Thani 12130, Thailand. Email: nakuntwalai_w@rmutt.ac.th

Received: 12 January 2019, Revised and Accepted: 19 July 2019

\section{ABSTRACT}

Objective: This study aims to investigate the effects of the Heliotropium indicum extract (HIE) on factor promoting wound healing in radical scavenging and inflammatory activity and growth factor promotion.

Methods: The radical scavenging capacity of HIE was evaluated by scavenging of 2,2-diphenyl-1-picrylhydrazyl (DPPH) and nitric oxide (NO) radicals. Furthermore, the anti-inflammatory of HIE was determined in a cellular model. RAW264.7 macrophage cells were treated with various concentrations of HIE before activating the treated cell with lipopolysaccharide (LPS). The nitrite concentration of activated macrophage was determined by the Griess reagent kit. The cell viability of RAW264.7 was evaluated by resazurin reduction assay as well as NIH3T3 fibroblast cells. In addition, production of the growth factors (transforming growth factor- $\beta$ [TGF- $\beta$ ] and basic fibroblast growth factor [bFGF]) of fibroblast was determined by Elisa kit.

Results: HIE exhibited radical scavenging activity in the DPPH and NO radicals with half maximal inhibitory concentration (IC ${ }_{50}$ ) at 0.22 mg/ml and $0.52 \mathrm{mg} / \mathrm{ml}$, respectively. In a cellular study, HIE inhibited NO production in LPS-stimulated macrophage without cytotoxic effect to the cells with IC ${ }_{50}$ at $87 \mu \mathrm{g} / \mathrm{ml}$. Furthermore, HIE promoted fibroblast cell viability at $72 \mathrm{~h}$ of treatment and, TGF- $\beta$ and bFGF production at $24 \mathrm{~h}$ of treatment.

Conclusion: These results obtained in this study suggested that HIE promoted the factors which involved in wound healing processes, including antiinflammatory effect with scavenged radical forming and inhibited activated-macrophage. Furthermore, HIE also stimulated growth factor production in fibroblast. These finding supported using traditional and folk medicine of $H$. indicum in wound treatment.

Keywords: Heliotropium indicum, Wound healing, Radical scavenging, Anti-inflammatory, Growth factors.

(c) 2019 The Authors. Published by Innovare Academic Sciences Pvt Ltd. This is an open access article under the CC BY license (http://creativecommons. org/licenses/by/4. 0/) DOI: http://dx.doi.org/10.22159/ijap.2019.v11s5.T0044

\section{INTRODUCTION}

Wound healing is a crucial physiological process that involves in communication of multiple cell types. The integration of cellular and molecular events occurs after the onset of tissue damage to a restoration of the injured tissues. The tissue restoration mechanism is continued with overlapping processes by hemostasis, inflammation, proliferation, and tissue remodeling [1].

Macrophages and fibroblast play critical roles in all phases of wound healing. After tissue injury, macrophages infiltrate to the lesion for phagocytosis of bacterial pathogens, foreign debris, and dead cells, and generate pro-inflammatory mediators resulting in inflammation [2]. In the inflammatory phase, macrophages are called M1 macrophages. They are activated to generate reactive oxygen species (ROS) as well as nitric oxide (NO) to contribute reactive nitrogen species (RNS) for clearance of pathogens and apoptotic cells. In addition, macrophages also generate pro-inflammatory mediators, for example, interleukin (IL)-1, IL-6, and tumor necrosis factor- $\alpha$ (TNF- $\alpha$ ) as well as growth factors, for example, basic fibroblast growth factor (bFGF), transforming growth factor- $\beta$ (TGF- $\beta$ ), vascular endothelial growth factor (VEGF), and platelet-derived growth factor (PDGF). These pro-inflammatory mediators and growth factors recruit endothelial cells, keratinocytes, and fibroblasts to heal the injured tissues [3]. In the late inflammatory phase, the pro-inflammatory M1 macrophages transit to anti-inflammatory M2 macrophages for production of antiinflammatory cytokines, for example, IL-4 and IL-10; meanwhile, inflammation is subsided let through the proliferative phase. In the remodeling phase, macrophages release matrix metalloproteinases to break down the temporary extracellular matrix (ECM) [4].
Fibroblasts are recruited to the wound site from the wound edge or the bone marrow after wounding. At the inflammation phase, fibroblasts produce several chemokines. At the proliferation phase, fibroblasts are activated within the wound site and differentiated to myofibroblasts to form granulation tissue. Both fibroblasts and myofibroblasts play a crucial role in generation of traction and contractile forces, respectively, to promote wound closure [5]. Fibroblasts also produce important growth factors including TGF- $\beta$ and bFGF.

TGF- $\beta$ is implicated in the control of fibroblast proliferation, and transformation of fibroblasts into myofibroblasts, production of the ECM, stimulation of collagen production, production of elastin, and synthesis of fibronectin, and inhibition of ECM degradation [6]. bFGF is also involved in the regulation of the replication and migration of epithelial, endothelial, and fibroblast cells, which participated in the production of collagen, epithelialization, and neovascularization, respectively [7].

In the case of chronic wound, it is found the excess production of ROS and RNS, which can directly interact with various biological targets. Macrophages are continuously activated to produce ROS, RNS, and pro-inflammatory cytokines including IL-1, IL-6, and TNF- $\alpha$ resulting in excess of inflammation where accompany with the limitation of growth factor, for example, TGF- $\beta$ and bFGF, production [8]. The immoderate inflammation cause an imbalance of the healing processes indicated that the proliferative and remodeling phases do not readily occur. This event originates chronic wound which does not heal in a timely manner $[9,10]$.

Heliotropium indicum is found in many paths of the world such as India, Africa, Bangladesh, Sri Lanka, Nepal, the Philippines, and Thailand. It has 
been used to cure various diseases in different traditional and folklore medicine system. In folk remedies, $H$. indicum has been used for treating fever, insect bite, diarrhea, skin rash, and herpes as well as wound and ulcer [11]. Furthermore, it has been reported that the application of the leaf paste of $\mathrm{H}$. indicum to heal rheumatism and skin infections as well as fresh cuts and wounds [12]. Previous studies in the animal model reported the healing promotion of $H$. indicum extract (HIE) in the incision and infected wound [12] as well as diabetic wound [13].

This study aims to examine the HIE on the factor promoting wound healing including (a) in vitro radical scavenging activity, (b) antiinflammatory activity in macrophage, (c) production of growth factors (TGF- $\beta 1$ and bFGF) in fibroblast, and (d) viability of macrophage and fibroblast cells. These results provide scientific support of using $H$. indicum in folklore medicine and a new direction for the promotion of wound healing.

\section{METHODS}

\section{Plant material}

H. indicum Linn. procured from Khaen Dong District, Buri Ram Province, Northeastern Thailand. The leaves of the plant were cleaned with water then dried at $50^{\circ} \mathrm{C}$ for $72 \mathrm{~h}$. The dried plant was grounded and stored at room temperature in vacuum. The extract was prepared by maceration of the grounded plant in $70 \%$ ethanol and shook at $250 \mathrm{rpm}$ with the shaker for $24 \mathrm{~h}$. The macerated mixture was filtrated for collected supernatant to evaporate at $50^{\circ} \mathrm{C}$ for $24 \mathrm{~h}$. The crude extract of $H$. indicum leaves was stored at $-20^{\circ} \mathrm{C}$ until used.

\section{2,2-diphenyl-1-picrylhydrazyl (DPPH) radical scavenging activity of HIE}

The HIE was first dissolved in a $2 \%$ dimethyl sulfoxide (DMSO), approximately $75 \mu \mathrm{l}$ of the dissolved HIE of variable concentrations $(0.0156,0.0312,0.0625,0.125,0.25,0.5,1$, and $2 \mathrm{mg} / \mathrm{ml})$ was mixed with $150 \mu \mathrm{l}$ of $0.2 \mathrm{mM}$ DPPH (Sigma-Aldrich USA) solution (in methanol) and allowed to stand for $30 \mathrm{~min}$ without direct exposure to light. The absorbance was determined at $520 \mathrm{~nm}$ using a microplate reader. In addition, DMSO and L-ascorbic acid were used as negative and positive controls, respectively. The DPPH scavenging capacity of the experimental HIE is presented as a percentage of DPPH radical inhibition as below, where OD is the optical density:

$\% \mathrm{DPPH}$ radical inhibition $=\left[\frac{\mathrm{OD}_{\text {without extract }}-\mathrm{OD}_{\text {with extract }}}{\mathrm{OD}_{\text {without extract }}}\right] \times 100$

\section{NO radical scavenging of HIE}

In this research, sodium nitroprusside (SNP) (Sigma-Aldrich, USA) was utilized as the NO donor. Specifically, $10 \mathrm{mM}$ of SNP in a pH7.4 PBS solution was incubated with $1 \mathrm{ml}$ dissolved HIE of variable concentrations $(0.0156,0.0312,0.0625,0.125,0.25,0.5,1$, and $2 \mathrm{mg} / \mathrm{ml})$ at $25^{\circ} \mathrm{C}$ for $180 \mathrm{~min}$. Approximately $100 \mu \mathrm{l}$ of the resulting solution was withdrawn to react with a Griess Reagent kit (Promega, USA) whereby the solution was reacted with $20 \mu \mathrm{l}$ sulfanilamide for $10 \mathrm{~min}$ and then $20 \mu \mathrm{l} \mathrm{N}$-1-naphthylethylenediamine dihydrochloride for another $10 \mathrm{~min}$. The reaction mixture absorbance was measured at $560 \mathrm{~nm}$, and the NO concentrations were determined as the nitrite $\left(\mathrm{NO}_{2}\right.$. $)$ concentrations from the standard curve of a standard nitrite solution. The reaction mixture absorbance was measured at $560 \mathrm{~nm}$. DMSO and L-ascorbic acid were used as negative and positive controls, respectively. The NO scavenging capacity of the experimental pectin is expressed as a percentage of nitrite production inhibition using the following formula:

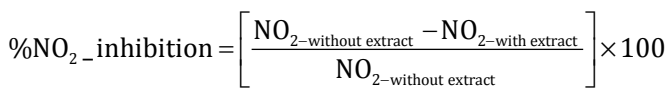

\section{Cell culture}

RAW264.7 murine macrophage and NIH3T3 murine fibroblast cell line were obtained from the American Type Culture Collection
(ATCC, Manassas, VA). The cells were maintained in Dulbecco's modified Eagle's medium (DMEM) (Gibco, USA) containing 10\% fetal bovine serum (Gibco, USA) and $100 \mathrm{U} / \mathrm{ml}$ penicillin and $100 \mu \mathrm{g} / \mathrm{ml}$ streptomycin (Gibco, USA) and incubated at $37^{\circ} \mathrm{C}$ in $5 \% \mathrm{CO}_{2} / 95 \%$ air humidified incubator. The RAW264.7 cell was subcultured using cell scraper twice a week, and 3T3 cell was subcultured using $0.25 \%$ trypsinEDTA (Gibco, USA) trypsinization. The cell viability was determined using $0.4 \%$ trypan blue (Sigma-Aldrich, USA) with cell viability $>85 \%$ and was used in all the experiments.

\section{NO production in the lipopolysaccharide (LPS)-stimulated macrophage}

The RAW264.7 macrophage cells $\left(2 \times 10^{5}\right.$ cell $\left./ \mathrm{ml}\right)$ were pretreated with the dissolved HIE of variable concentrations $(6.25,12.5,25$, 50 , and $100 \mu \mathrm{g} / \mathrm{ml}$ ) in a 96-well plate and incubated at $37^{\circ} \mathrm{C}$ for $24 \mathrm{~h}$. The pre-treated cells were stimulated with $1 \mu \mathrm{g} / \mathrm{ml}$ of LPS and incubated for another $24 \mathrm{~h}$. The NO concentrations were determined from nitrite $\left(\mathrm{NO}_{2}\right.$ ) in the stimulated-cell supernatant using a Griess Reagent Kit whereby $100 \mu \mathrm{l}$ of the supernatant was reacted with $20 \mu \mathrm{l}$ sulfanilamide for $10 \mathrm{~min}$ and with $20 \mu \mathrm{l}$-1-naphthylethylenediamine dihydrochloride for another $10 \mathrm{~min}$. The reaction mixture absorbance was measured at $560 \mathrm{~nm}$, and the NO concentrations were determined as the nitrite $\left(\mathrm{NO}_{2}\right.$ ) concentrations from the standard curve of a standard nitrite solution. About $0.2 \%$ DMSO and $100 \mu \mathrm{M}$ of dexamethasone each with $1 \mu \mathrm{g} / \mathrm{ml}$ LPS were, respectively, used as the negative and positive controls.

\section{Determination of cell viability of RAW264.7 macrophage cells}

The viability of the residual macrophage cells after the NO assay, given HIE concentrations of $6.25,12.5,25,50$, and $100 \mu \mathrm{g} / \mathrm{ml}$, was examined by resazurin (Sigma-Aldrich, USA) reduction assay, whereby the residual cells were incubated for $2 \mathrm{~h}$ at $37^{\circ} \mathrm{C}$ in $100 \mu \mathrm{l}$ fresh DMEM containing $50 \mu \mathrm{g} / \mathrm{ml}$ resazurin. The reaction mixture absorbance was determined at 560 against $600 \mathrm{~nm}$. The cell viability of the RAW264.7 macrophage cells was presented as percentage cell viability using the following formula:

$\%$ Cell viability $=\left[\frac{\left(\mathrm{OD}_{560}-\mathrm{OD}_{600}\right)_{\text {with extract }}}{\left(\mathrm{OD}_{560}-\mathrm{OD}_{600}\right)_{\text {without extract }}}\right] \times 100$

\section{Determination of cell viability of NIH3T3 fibroblast cells}

The NIH3T3 fibroblast cells $\left(4 \times 10^{5} \mathrm{cell} / \mathrm{ml}\right)$ were seeded in a 96 -well plate and incubated at $37^{\circ} \mathrm{C}$ for $24 \mathrm{~h}$. The cells were treated with the variable of HIE concentrations at $6.25,12.5,25,50$, and $100 \mu \mathrm{g} / \mathrm{ml}$ for 24,48 , and $72 \mathrm{~h}$. The cell viability was determined by resazurin (Sigma-Aldrich, USA) reduction assay, whereby the cells were incubated for $4 \mathrm{~h}$ at $37^{\circ} \mathrm{C}$ in $100 \mu \mathrm{l}$ fresh DMEM containing $50 \mu \mathrm{g} / \mathrm{ml}$ resazurin. The reaction mixture absorbance was determined at 560 against $600 \mathrm{~nm}$. The cell viability of the NIH3T3 fibroblast cells was presented as percentage cell viability using the above formula.

\section{TGF- $\beta$ and bFGF production in fibroblast cells}

The NIH3T3 fibroblast cells $\left(4 \times 10^{5} \mathrm{cell} / \mathrm{ml}\right)$ were seeded into 24 -well plate at $37^{\circ} \mathrm{C}$ for $24 \mathrm{~h}$. The cells were treated with the variable of HIE concentration at $12.5,25$, and $50 \mu \mathrm{g} / \mathrm{ml}$ for another $24 \mathrm{~h}$. The supernatant was collected to determine TGF- $\beta$ and bFGF levels, respectively, using TGF- $\beta 1$ Mouse Elisa kit (Abcam, USA) and bFGF Mouse Elisa kit (Sigma-Aldrich, USA) according to the manufacturer's protocol.

\section{Statistical analysis}

In this study, data from at least three independent experiments carried out in triplicate. The statistical data were expressed as mean with a standard error of the mean. The negative control group was compared against the experimental group using one-way ANOVA with Tukey's honestly significant difference (HSD) post hoc test, with the $5 \%$ $\left({ }^{*} \mathrm{p}<0.05\right)$ and $1 \%\left({ }^{* *} \mathrm{p}<0.01\right)$ significance level. 


\section{RESULTS}

DPPH scavenging capacity of HIE

In this study, the DPPH scavenging capacity of HIE is evaluated by the percentage of DPPH free radical inhibition and half maximal inhibitory concentration $\left(\mathrm{IC}_{50}\right) . \mathrm{IC}_{50}$ is the IC at which the DPPH radicals are scavenged by $50 \%$. The results revealed that with $0.0156-2 \mathrm{mg} / \mathrm{ml}(0.0156,0.0312,0.0625,0.125,0.25,0.5,1$, and

Table 1: DPPH and NO half maximal inhibitory concentrations of HIE and L-ascorbic acid

\begin{tabular}{lll}
\hline Testing compound & \multicolumn{2}{l}{$\begin{array}{l}\text { IC }_{50} \text { of free radical scavenging } \\
(\mathbf{m g} / \mathbf{m l})\end{array}$} \\
\cline { 2 - 3 } & $\mathbf{D P P H}$ & NO \\
\hline HIE & 0.22 & 0.52 \\
L-ascorbic acid & 0.030 & 0.034 \\
\hline
\end{tabular}

DPPH: 2,2-diphenyl-1-picrylhydrazyl, NO: Nitric oxide,

HIE: Heliotropium indicum extract, $\mathrm{IC}_{50}$ : Half maximal inhibitory concentration

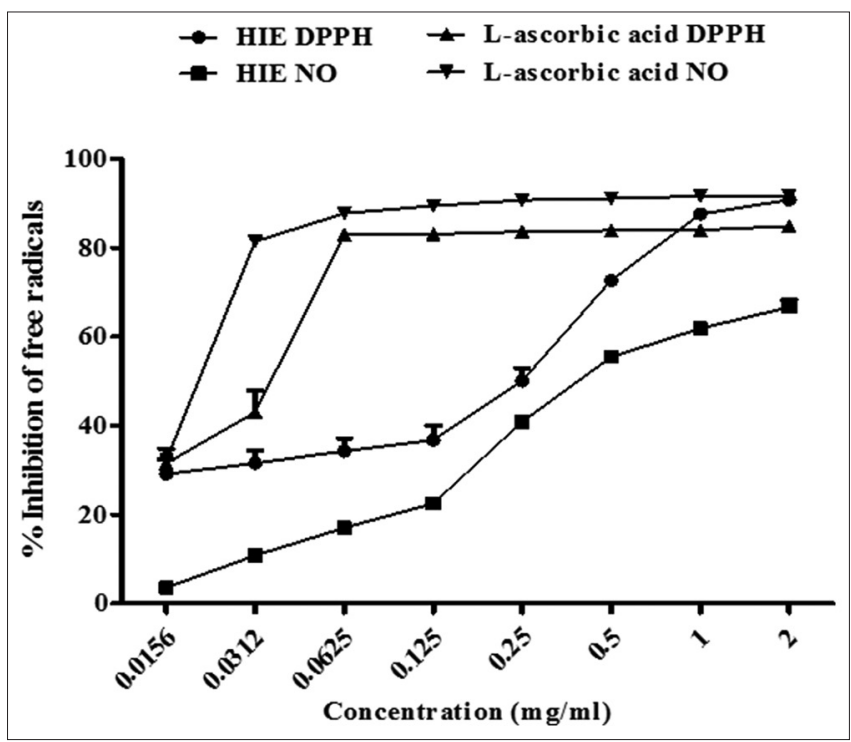

Fig. 1: The nitric oxide (nitrite) inhibition efficiency (\%) under variable Heliotropium indicum extract (HIE) and L-ascorbic acid concentrations, compared with HIE-free dimethyl sulfoxide (the negative control). The values are means \pm standard error of the mean. L-ascorbic acid is used as the positive control
$2 \mathrm{mg} / \mathrm{ml}$ ) of HIE concentrations, HIE significantly reduces DPPH radicals, achieving the inhibition performance in the range of $29.17 \pm 5.62-90.78 \pm 1.17 \%$ (Fig. 1); and an IC ${ }_{50}$ of $0.22 \mathrm{mg} / \mathrm{ml}$. Meanwhile, $\mathrm{L}$-ascorbic acid at the same concentration which used as the positive control exhibits the inhibition efficiency of $31.53 \pm 3.90-84.88 \pm 0.29 \%$ (Fig. 1); and an $\mathrm{IC}_{50}$ of $0.030 \mathrm{mg} / \mathrm{ml}$ (Table 1).

\section{NO scavenging capacity of HIE}

The experimental results reveal that HIE could scavenge the NO radicals. In the negative control with the absence of HIE (DMSO) presented a high nitrite (a stable product of NO) concentration while the positive control (L-ascorbic acid) inhibited the nitrite $\left(\mathrm{NO}_{2}\right)$ formation. The resulted revealed that with $0.0156-2 \mathrm{mg} / \mathrm{ml}(0.0156,0.0312,0.0625$, $0.125,0.25,0.5,1$, and $2 \mathrm{mg} / \mathrm{ml}$ ) of HIE concentrations, HIE significantly reduces $\mathrm{NO}$ formation, achieving the scavenging performance in the range of $3.59 \pm 0.46-66.61 \pm 2.87 \%$ (Fig. 1); and an $\mathrm{IC}_{50}$ of $0.52 \mathrm{mg} / \mathrm{ml}$ (Table 1), where $\mathrm{IC}_{50}$ is the IC at which the NO radicals are scavenged by $50 \%$. By comparison, L-ascorbic acid (the positive control) at the same concentrations achieved the inhibition performance of $32.26 \pm 0.86-91.72 \pm 0.19 \%$ (Fig. 1); and an $\mathrm{IC}_{50}$ of $0.034 \mathrm{mg} / \mathrm{ml}$ (Table 1).

Effect of HIE on NO production and cell viability in LPS-stimulated macrophage

In this study, the RAW264.7 macrophage cells were treated with variable concentrations of HIE $(6.25,12.5,25,50$, and $100 \mu \mathrm{g} / \mathrm{ml})$ for $24 \mathrm{~h}$ before activating with $1 \mu \mathrm{g} / \mathrm{ml}$ LPS. Furthermore, DMSO and $100 \mu \mathrm{M}$ of dexamethasone each with LPS were, respectively, used as the negative and positive controls. In Fig. 2a, the experimental results showed that the nitrite $\left(\mathrm{NO}_{2}\right)$ concentration in the LPS-stimulated macrophage was decreased in HIE-treated cells, achieving the inhibition performance in the range of $16.64 \pm 1.70-54.87 \pm 1.86 \%$ (Fig. $2 \mathrm{a}$ ); and an $\mathrm{IC}_{50}$ of $87 \mu \mathrm{g} / \mathrm{ml}$. The NO inhibition is more obvious in the treatment with $12.5-100 \mu \mathrm{g} / \mathrm{ml}$ HIE concentrations. The dexamethasone-treated cells (positive control) achieved NO inhibition performance by $64.51 \pm 6.63 \%$ (Fig. 2a)

In Fig. 2b, the viability of the RAW264.7 macrophage cells was assessed by a resazurin reduction assay and the effective HIE concentrations determined. DMSO and dexamethasone each with $1 \mu \mathrm{g} / \mathrm{ml}$ LPS were, respectively, used as the negative and positive controls. In general, the cell viability and NO production are positively correlated. Given the non-cytotoxicity of HIE, the HIE-treated cells could achieve high NO inhibition performance with no effect to cell viability.

\section{Effect of HIE on fibroblast cell viability}

The cell viability of the NIH3T3 fibroblast cells was examined by resazurin reduction assay. DMSO was used as negative control. In Fig. 3, the fibroblast cells were treated with variable concentration of HIE $6.25-100 \mu \mathrm{g} / \mathrm{ml}$. The results indicate that the cell viability of HIE-treated cell for 24,48 , and $72 \mathrm{~h}$ trend to increase. However, the cell viability of 24 and $48 \mathrm{~h}$ of treatment was not significantly different from the control (DMSO treated-

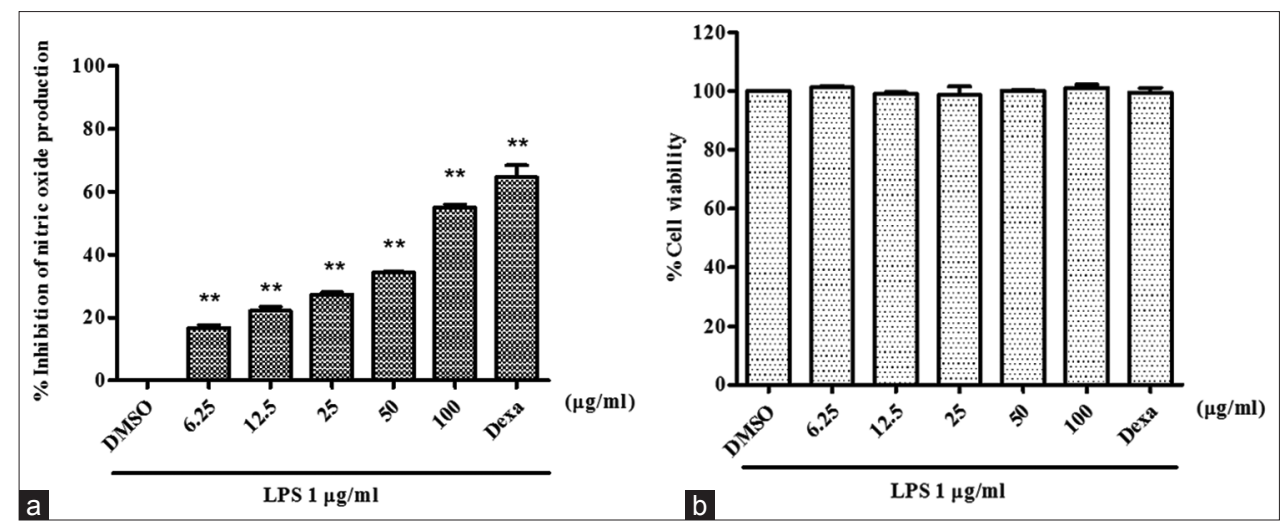

Fig. 2: Effect of variable Heliotropium indicum extract concentration in $1 \mu \mathrm{g} / \mathrm{ml}$ lipopolysaccharide-stimulated RAW264.7 macrophage: (a) Percentage of nitric oxide inhibition, (b) cell viability. The values are means \pm standard error of the mean. ${ }^{* *}$ denote p<0.01. Dimethyl sulfoxide and dexamethasone are, respectively, used as negative and positive controls 
cells). For $72 \mathrm{~h}$ of HIE-treated cells, the cell viability is more pronounced in treatment with $50 \mu \mathrm{g} / \mathrm{ml}$ HIE concentration-treated cell (Fig. 3).

\section{Effect of HIE on TGF- $\beta 1$ and bFGF production in fibroblast cells} The growth factors, TGF- $\beta 1$, and bFGF are determined by ELISA kit. The results exhibited that HIE with a concentration of $12.5,25$, and $50 \mu \mathrm{g} / \mathrm{ml}$ significantly increase the production of TGF- $\beta 1$ (Fig. 4a) and bFGF (Fig. 4b).

\section{DISCUSSION}

Wound healing is the coordination and dynamic process that involves in many cell types, including macrophages and fibroblasts as well as their cytokines and growth factors. Macrophages promote and resolute inflammation, remove apoptotic or debris cells, and support cell proliferation, which makes equable of wound healing process [14]. However, macrophages have the potential to disturb different phases of repair, and persistent macrophage activation can lead to maladaptive, chronic inflammation, and dysfunction wound healing [15]. Macrophages continue to produce NO and ROS in prolonging inflammation that can cause to wound surrounding cell injury and chronic wound [16]. The previous study demonstrated that the chronic wound both infected and noninfected wounds improved by antioxidant, where it scavenges the excess free radicals to reduce the damage caused. In addition, the previous study revealed the correlation

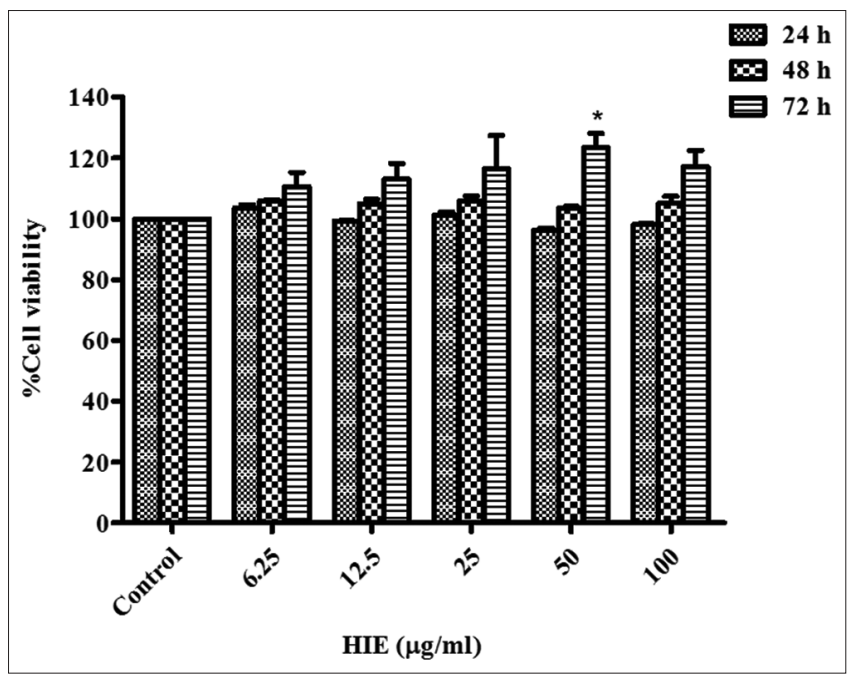

Fig. 3: The effects of variable Heliotropium indicum extract concentrations treated cell for 24,48 , and 72 h on cell viability of NIH3T3 fibroblast cells. The values are mean \pm standard error of the mean. *denote p<0.05. $0.2 \%$ dimethyl sulfoxide is used as negative control of radical scavenging properties of Sphaeranthus amaranthoides and wound healing improvement in mice [17]. This current study showed that HIE effectively scavenged free radical, DPPH, and NO. Based on these results, radical scavenging activity of HIE belongs to the enhancement of wound healing.

Moreover, the results also revealed the anti-inflammatory property of HIE through inhibition of NO production in activated macrophages. In general, although NO is a physiological signaling molecule, inordinate inducible $\mathrm{NO}$ becomes oxidative molecule which can interact with $\mathrm{O}_{2}$ - to produce cytotoxic oxidant peroxynitrite $\left(\mathrm{ONOO}^{-}\right)$. The peroxynitrite is a powerful oxidant initiate cleavage DNA resulting in cell damage [18]. Prolong activation of macrophages cause to continue production of NO associated with chronic inflammation that impedes proliferation stage in the wound healing process [19]. The previous study revealed that failure in the change of M1 inflammatory macrophage to M2 antiinflammatory macrophage phenotype caused to prolong inflammatory stage of wound healing where delay in transition to the proliferative stage [20]. Furthermore, suppression of M1 inflammatory macrophage and enhancement of M2 anti-inflammatory macrophage polarization together with degradation of receptor interacting protein 140 became anti-inflammation to promote diabetic chronic wound healing in mice [21]. In this study, HIE inhibited the production of NO in activated macrophage and given non-cytotoxic to the cells, suggested that the limitation of inflammation, where to support the initiation of proliferation stage of wound healing.

Proliferative stage of wound healing occurs after the subsidence of inflammation where the major focus on re-epithelialization, vascular network restoration, and granulation tissue formation. Fibroblasts play important roles to form the granulation tissue. They migrate from the nearby dermis to the wound in response to cytokines and growth factors produced by platelets and macrophages in the wounds, for example, PDGF, TGF- $\beta$, and bFGF. In addition, fibroblasts also produce cytokines, chemokines, and growth factors to enhance angiogenesis [22]. bFGF and TGF- $\beta 1$ are key growth factors implicating in the process of wound healing.

In this study, TGF- $\beta 1$ and bFGF were upregulated in HIE-treated fibroblast cells. The previous study demonstrated that aloe vera can stimulate TGF- $\beta 1$ and bFGF production in mouse embryonic fibroblast cell [23] as well as Panax ginseng encouraged TGF- $\beta 1$, collagen type I, and VEGF production in NIH3T3 fibroblast cells [24]. These growth factors are important in the improvement of chronic wound healing. TGF- $\beta 1$ regulates several cell functions, for example, proliferation, differentiation, apoptosis, cell adhesion, cell motility, and ECM production [25]. bFGF regulates replication and migration of epithelial, endothelial, and fibroblast cells which implicated in collagen production, epithelialization, and neovascularization of the wound healing process [26]. The upregulation of these growth factors in
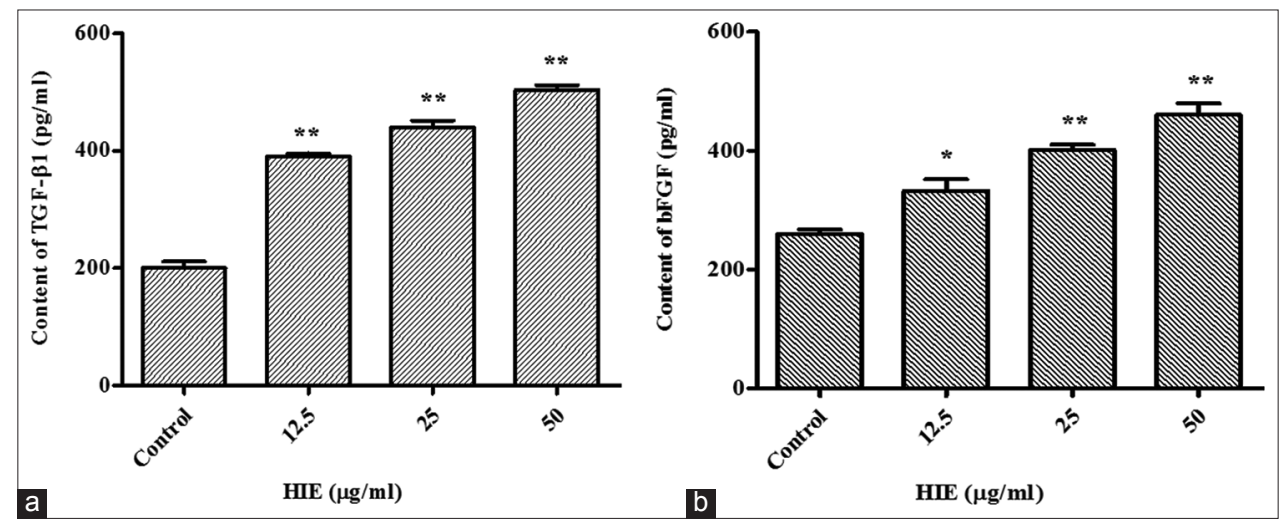

Fig. 4: The effects of variable Heliotropium indicum extract concentrations treated cell for $24 \mathrm{~h}$ on growth factor production in NIH3T3 fibroblast cells: (a) Transforming growth factor- $\beta 1$, (b) basic fibroblast growth factor. The values are mean \pm standard error of the mean. *and ${ }^{* *}$, respectively, denote $\mathrm{p}<0.05$ and $\mathrm{p}<0.01 .0 .2 \%$ dimethyl sulfoxide is used as negative control 
function and production can help wound repair, especially the chronic wounds which presented growth factor deficiency.

In an animal model study, HIE promoted the healing of excision (normal and infected), incision, and dead space wound models [12], and excision wound in streptozotocin-induced diabetic rats [13]. The findings from our research in the cellular study provide a better understanding of the function of HIE in wound healing improvement. Given antioxidant, anti-inflammatory properties, and growth factors promotion of HIE, the extract could thus be applied to encourage chronic wound healing and increase the possibility of therapeutic application of HIE in wound healing. However, further phytochemical studies of HIE are required to separate the active compounds responsible for these pharmacological activities.

\section{CONCLUSION}

This experimental research has investigated the scavenging ability of HIE of variable concentration $(0.0156-2 \mathrm{mg} / \mathrm{ml})$ on DPPH and NO free radicals; anti-inflammatory property through inhibition of NO production in LPS-stimulated macrophage cells; and cell viability of LPS-stimulated macrophage and fibroblast cells, given the HIE concentration $6.25-100 \mu \mathrm{g} / \mathrm{ml}$; and promotion of TGF- $\beta 1$ and bFGF growth factors in fibroblast cells, given the HIE concentrations of $12.5-50 \mu \mathrm{g} / \mathrm{ml}$. The experimental results revealed that the DPPH and NO scavenging performance and the HIE concentration are positively correlated, with the corresponding $\mathrm{IC}_{50}$ of 0.22 and $0.52 \mathrm{mg} / \mathrm{ml}$. In addition, inhibition of NO production in LPS-stimulated RAW264.7 macrophage cells is also positively correlated to the HIE concentrations with no effect to cell viability. The experimental results also revealed that the cell viability of fibroblast trend to increase in $72 \mathrm{~h}$ of HIE treatment. Moreover, the results also presented the promotion of TGF- $\beta 1$ and bFGF growth factors production in HIE-treated fibroblast cells. The findings demonstrate the benefit of HIE in wound healing promotion.

\section{ACKNOWLEDGMENT}

The authors would like to extend deep gratitude to Thai Traditional Medicine College for laboratory support. Appreciation also goes to Rajamangala University of Technology Thanyaburi (RMUTT) for the research grant.

\section{REFERENCES}

1. Gonzalez AC, Costa TF, Andrade ZA, Medrado AR. Wound healing-A literature review. An Bras Dermatol 2016;91:614-20.

2. Krzyszczyk P, Schloss R, Palmer A, Berthiaume F. The role of macrophages in acute and chronic wound healing and interventions to promote pro-wound healing phenotypes. Front Physiol 2018;9:419.

3. Frykberg RG, Banks J. Challenges in the treatment of chronic wounds. Adv Wound Care (New Rochelle) 2015;4:560-82.

4. Saqib U, Sarkar S, Suk K, Mohammad O, Baig MS, Savai R. Phytochemicals as modulators of M1-M2 macrophages in inflammation. Oncotarget 2018;9:17937-50.

5. Muthusubramaniam L, Zaitseva T, Paukshto M, Martin G, Desai T. Effect of collagen nanotopography on keloid fibroblast proliferation and matrix synthesis: Implications for dermal wound healing. Tissue Eng Part A 2014;20:2728-36.

6. Faler BJ, Macsata RA, Plummer D, Mishra L, Sidawy AN. Transforming growth factor-beta and wound healing. Perspect Vasc Surg Endovasc Ther 2006;18:55-62.

7. Tang QL, Han SS, Feng J, Di JQ, Qin WX, Fu J, et al. Moist exposed burn ointment promotes cutaneous excisional wound healing in rats involving VEGF and bFGF. Mol Med Rep 2014;9:1277-82.

8. André-Lévigne D, Modarressi A, Pepper MS, Pittet-Cuénod B. Reactive oxygen species and NOX enzymes are emerging as key players in cutaneous wound repair. Int J Mol Sci 2017;18:E2149.

9. Sindrilaru A, Peters T, Wieschalka S, Baican C, Baican A, Peter H, et al. An unrestrained proinflammatory M1 macrophage population induced by iron impairs wound healing in humans and mice. J Clin Invest 2011:121:985-97.

10. Barrientos S, Stojadinovic O, Golinko MS, Brem H, Tomic-Canic M. Growth factors and cytokines in wound healing. Wound Repair Regen 2008:16:585-601.

11. Dash GK, Abdullah MS. A review on Heliotropium indicim L. (BORAGINACEAE). Int J Pharm Sci Res 2013;4:1253-8

12. Dash GK, Murthy PN. Studies on wound healing activity of Heliotropium indicum Linn. leaves on rats. ISRN Pharmacol 2011;2011:847980.

13. Ayisha SA, Baskaran K. Wound healing potential of ethanolic leaf extract of Heliotropium indicum on excision wound model in diabetic rats. Int J Pharm 2016;7:155-8.

14. Koh TJ, DiPietro LA. Inflammation and wound healing: The role of the macrophage. Expert Rev Mol Med 2011;13:e23.

15. Gensel JC, Zhang B. Macrophage activation and its role in repair and pathology after spinal cord injury. Brain Res 2015;1619:1-11.

16. Miao MY, Niu YW, Xie T, Yuan B, Qing C, Lu SL. Diabetes-impaired wound healing and altered macrophage activation: A possible pathophysiologic correlation. Wound Repair Regen 2012;20:203-13.

17. Geethalakshmi R, Sakravarthi C, Kritika T, Arul Kirubakaran M, Sarada DV. Evaluation of antioxidant and wound healing potentials of Sphaeranthus amaranthoides Burm.f. Biomed Res Int 2013;2013:607109.

18. Redza-Dutordoir M, Averill-Bates DA. Activation of apoptosis signalling pathways by reactive oxygen species. Biochim Biophys Acta 2016;1863:2977-92.

19. Zhao RL, Liang HL, Clarke E, Jackson C, Xue ML. Inflammation in chronic wounds. Int J Mol Sci 2016;17:E2085.

20. Bannon P, Wood S, Restivo T, Campbell L, Hardman MJ, Mace KA. Diabetes induces stable intrinsic changes to myeloid cells that contribute to chronic inflammation durin g wound healing in mice. Dis Model Mech 2013;6:1434-47.

21. Lin YW, Liu PS, Pook KA, Wei LN. Glyburide and retinoic acid synergize to promote wound healing by anti-inflammation and RIP140 degradation. Sci Rep 2018;8:834

22. Landén NX, Li DQ, Ståhle M. Transition from inflammation to proliferation: A critical step during wound healing. Cell Mol Life Sci 2016;73:3861-85.

23. Hormozi M, Assaei R, Boroujeni MB. The effect of Aloe vera on the expression of wound healing factors (TGF $\beta 1$ and $\mathrm{bFGF}$ ) in mouse embryonic fibroblast cell: In vitro study. Biomed Pharmacother 2017;88:610-6.

24. Chen XN, Wang MY, Xu XH, Liu ZJ, Mei B, Fu PP, et al. Panax ginseng total protein promotes proliferation and secretion of collagen in NIH/3T3 cells by activating extracellular signal-related kinase pathway. J Ginseng Res 2017;41:411-8.

25. Li C, Gotlieb AI. Transforming growth factor- $\beta$ regulates the growth of valve interstitial cells in vitro. Am J Pathol 2011;179:1746-55.

26. Weber TJ, Shankaran H, Wiley HS, Opresko LK, Chrisler WB, Quesenberry RD. Basic fibroblast growth factor regulates persistent ERK oscillations in premalignant but not malignant JB6 cells. J Invest Dermatol 2010;130:1444-56. 